\title{
Generation of HEK-293 stable cell lines with disrupted expression of ribosomal protein S6 kinase (S6K1) isoforms using the CRISPR/Cas9 genome editing system
}

\author{
I. V. Zaiets, A. S. Sivchenko, A. I. Khoruzhenko, V. V. Filonenko \\ Institute of Molecular Biology and Genetics, NAS of Ukraine \\ 150, Akademika Zabolotnoho Str., Kyiv, Ukraine, 03680 \\ filonenko@imbg.org.ua
}

\begin{abstract}
Aim. To generate HEK-293 cells with disrupted expression of S6K1 isoforms: p85, p70 and p60. Methods. CRISPR/Cas9 gene editing, Western blotting, immunofluorescent analysis, RT-PCR analysis, MTT assay, scratch assay. Results. Several clones of HEK-293 cells with a complete loss of $\mathrm{p} 85 / \mathrm{p} 70 / \mathrm{p} 60-\mathrm{S} 6 \mathrm{~K} 1$ protein expression were generated. The effects of $\mathrm{p} 85 /$ p70/p60-S6K1 knockout on Akt/mTORC1/S6K1 signaling and cell proliferation and migration were assessed. Conclusions. The generated cell lines can be used to study a role played by S6K1 in cell physiology and to gain more detailed insight into cellular functions of the S6K1 isoforms. The HEK-293 cells exhibit downregulation of Akt phosphorylation on Ser473 and subsequent attenuation of cell growth rate, as well as inhibition of cell motility.
\end{abstract}

Ke y w o r d s: mTOR/S6K1 signaling, CRISPR/Cas9, S6K1 isoforms.

\section{Introduction}

Ribosomal protein S6 kinase (S6K1) functions as a component of the mTOR/S6K-dependent signaling pathway that is a critical regulator of translation, cell growth, survival and proliferation (reviewed in $[1,2])$. S6K1 is an extensively studied serine/threonine kinase that exerts its effects downstream of mTORC1 (mammalian target of rapamycin complex 1). The deregulation of the mTORC1/S6K1 signaling axis has been linked to a number of disease states, including cancer progression, metabolic and neurological disorders and aging-related pathologies [3-5].

The human RPS6KB1 gene encoding S6 kinase 1 resides within the $17 \mathrm{q} 23$ chromosome locus. Alternative splicing events or alternate translational start site utilization yield specific S6K1 protein isoforms. To date, the evidence suggests the existence of several S6K1 isoforms, including the well-studied $70 \mathrm{kDa}$ S6K 1 and $85 \mathrm{kDa}$ S6K1 (p70-S6K1 and p85-S6K1 respectively), an oncogenic $31 \mathrm{kDa} \mathrm{S} 6 \mathrm{~K} 1$ (p31-S6K1 or S6K1-isoform 2) and a $60 \mathrm{kDa}$ S6K1 (p60-S6K1). The p70-S6K1 and p85-

(C) 2017 I. V. Zaiets et al.; Published by the Institute of Molecular Biology and Genetics, NAS of Ukraine on behalf of Biopolymers and Cell. This is an Open Access article distributed under the terms of the Creative Commons Attribution License (http://creativecommons.org/licenses/by/4.0/), which permits unrestricted reuse, distribution, and reproduction in any medium, provided the original work is properly cited 
S6K1 isoforms differ only by the presence of an N-terminal 23 aa extension due to alternative ATG site usage ( $\mathrm{p} 85$-S6K1 translates from the first ATG and p70-S6K1 from the second one) [6]. The origin of another S6K1 isoform, p60-S6K1, is not known, however, it is believed that it may represent a protein translated from an alternative translation start site [7], possibly a third ATG located $87 \mathrm{bp}$ downstream of the second one. This is supported by PCR analysis data, as well as the data of Western Blot analysis which reveal that only antibodies specific to the C-terminal region of S6K1 (but not to the N-terminal region) can recognize p60-S6K1 [7].

Experiments using transgenic mice [8] indicate that RPS6KB1 gene knockout significantly affects mice phenotype demonstrating a significant decrease in body size, enhanced sensitivity to insulin and, as a consequence, resistance to high fat diet-induced obesity [8-10]. At the same time, RPS6KB1 knockout does not have a lethal effect on these mice, probably due to the existence of S6K2 that is highly homologous to $\mathrm{S} 6 \mathrm{~K} 1$ and shares most of substrates. Amplification of RPS6KB1 gene was found in tumors of different histotypes, including breast carcinoma where it was initially detected [1113]. The results obtained in $[14,15]$ demonstrated that overexpression of S6K1 is accompanied by the kinase nuclear accumulation, and a correlation between S6K1 expression and tumor cell aggressiveness was observed [16, 17]. In addition, there are some data indicating that resistance of estrogen positive tumors to anti-estrogen therapy is tightly linked to S6K1 signaling $[18,19]$. Despite numerous data suggesting the oncogenic potential of S6K1, the contribution of each isoform is not clear yet.
To evaluate the functional activity of different isoforms of S6K1 as well as their oncogenic properties we planned to generate model cell lines with exclusive expression of specific S6K1 isoforms (p85, or p70, or p60).

The main goal of present work was to produce the basic HEK-293 cells with a knockout of RPS6KB1 gene expression on protein level applying CRISPR/Cas9-mediated gene editing. The Clustered Regularly Interspaced Short Palindromic Repeats (CRISPR)/CRISPR-associated protein 9 nuclease (Cas9) is a prokaryotic adaptive immune system which has been used for genome engineering in recent years [20-22]. This genome editing system is based upon using a guide RNA (gRNA) sequence and the Cas9 endonuclease to introduce double-strand breaks in the targeted gene sequence that is complementary to gRNA. The genome double-strand breaks stimulate error-prone non-homologous end-joining (NHEJ) repair introducing mutagenic insertions or deletions (InDels) at the DSB site, as well as highfidelity but less efficient Homology Directed Repair (HDR).

Once RPS6KB1 knockout in HEK-293 has been confirmed by PCR, Western blot and immunofluorescence analysis, we analyzed how it affected phosphorylation status of the major S6K1 substrates, cell proliferation and their migratory potential. These cells will be further used for generation of HEK-293 cells exhibiting particular expression of different $\mathrm{S} 6 \mathrm{~K} 1$ isoforms.

\section{Materials and Methods}

gRNA design and cloning. gRNA oligonucleotides complementary to the sequence of the target gene were designed using the web tool http://crispr.mit.edu/. The sequences of gRNA oligonucleotides are the following: top strand - 
CACCGACTTCGGGTACTTGGTAAAG, bottom strand - AAACCTTTACCAAGTACCCG AAGTC, where the sequences underlined with a solid line correspond to the sequence of the S6K1 gene and the sequences without lines correspond to the Esp3I restriction site sequence. To clone the gRNA oligonucleotides in pSpCas9(BB)-2A-Puro (PX459) V2.0 vector (Addgene) they were annealed and ligated with the vector treated with the Esp3I restriction enzyme. For a ligation reaction T4 DNA ligase (ThermoScientific) was used. After ligation the construct was cloned in E.coli strain XL-GOLD. The presence of the insert was verified using PCR amplification and sequencing. For PCR amplification a primer corresponding to the U6 promoter was used as a forward primer (GAG GGCCTATTTCCCAT GATTCC) and the bottom gRNA oligonucleotide (AAACCTTTACC AAGTACCCGAAGTC) as a reverse primer. Sequencing of the insert was performed by using Applied Biosystems ${ }^{\mathrm{TM}} 3130$ DNA Analyzer.

Cell culture and generation of HEK-293 cells with the edited S6K1 gene. Human embryonic kidney cells (HEK-293) were maintained in DMEM medium containing $10 \%$ heat-inactivated fetal bovine serum (FBS) (GIBCO), 100 units/ml penicillin, and $100 \mu \mathrm{g} /$ $\mathrm{ml}$ streptomycin. Transfection of S6K1 specific gRNAs into HEK-293 cells was carried out using jetPEI transfection reagent (Polyplustransfection $\left({ }^{\circledR} \mathrm{SA}\right)$. The procedure was performed following manufacturer's instructions. The cells were seeded onto a 24-well plate before transfection. The cells were grown for 24 hours following transfection with $1 \mu \mathrm{g}$ of DNA (pSpCas9(BB)-2A-Puro (PX459) V2.0/ $\mathrm{S} 6 \mathrm{~K} 1)$. The cells were seeded onto 10 -sm cell culture dishes 24 hours posttransfection and selected with puromycin $(4 \mu \mathrm{g} / \mathrm{mL})$ for 48 hours. After selection the clones were picked up. The cells were cultured in an incubator with $5 \% \mathrm{CO} 2$ at $37 \mathrm{C}$.

Western blot analysis. Cells were washed with ice-cold PBS and lysed on ice for $30 \mathrm{~min}$ in $20 \mathrm{mM}$ Tris- $\mathrm{HCl}, \mathrm{pH} 7.5,150 \mathrm{mM} \mathrm{NaCl}$, $1 \mathrm{mM}$ EDTA, $1 \mathrm{mM}$ EGTA, $0.5 \%$ Triton X-100, supplemented with a Complete EDTAfree protease inhibitor cocktail tablet (Roche). Whole-cell lysates were centrifuged at 12,000 $\mathrm{g}$ for $15 \mathrm{~min}$ at $+4{ }^{\circ} \mathrm{C}$, and the supernatant was collected. The protein concentrations were determined using Bradford assay. Equal amounts of protein were resolved on $10 \%$ SDS-PAGE and electrotransferred onto polyvinylidene difluoride (PVDF) membranes for immunoblotting. The antibodies were diluted for use as follows: anti-S6K1-C-terminus (generated as described in [23]) 1:2500, anti- $\beta$ actin (clone 13E5, Sigma) 1:20000, anti-phopho-S6 ribosomal protein (Ser235/236) (\#2211, Cell Signaling Technologies) 1:2000, antiphospho-S6 ribosomal protein (Ser240/244) (\#5364, Cell Signaling Technologies) 1:2000, anti-phospo-eIF4B (Ser422) (\#3591, Cell Signaling Technologies) 1:2000, anti-phosphoeEF-2K (Ser366) (\#3691, Cell Signaling Technologies) 1:2000, anti-phospho-Akt (Ser473) (\#9271, Cell Signaling Technologies) 1:2000.

PCR analysis of cDNA from HEK293 clones. The efficiency of CRISPR/Cas9 in HEK-293 was checked by RT-PCR. Total mRNA was isolated from cells using GeneJET RNA purification kit (ThermoScientific). cDNA was synthesized with RevertAid using oligo(dT) 18 according to manufacturer's recommendations (ThermoScientific). RT-PCR analysis was done with DreamTaq DNA poly- 
merase (ThermoScientific). The following primers were used for PCR amplification: for the 5'-end of the S6K1 transcript sequence Forward (F1) - CTTCCGAGACAGGGAAG CTG, Reverse (R1) - GCCAAGTAAAAGC AGGCAGTG; for the 3'-end of S6K1 - Forward (F2) - CACCTCGAAGATTTATTGGCA, Reverse (R2) - GTGCTCTGGCCGTTTGG.

Immunofluorescent analysis of HEK-293 clones. HEK-293 cells (clones 5 and 6) were seeded onto cover glasses and cultured several days. After reaching 70-80\% of confluent monolayer, cells were fixed with $10 \%$ neutral buffered formalin. Thereafter, the cells were permeabilized by $15 \mathrm{~min}$ incubation in $100 \mu \mathrm{l}$ PBS with $0.2 \%$ Triton X-100. Non-specific binding was blocked by incubation with $10 \%$ FCS in PBS for $30 \mathrm{~min}$ at $37^{\circ} \mathrm{C}$. For S6K1 detection samples were incubated with rabbit polyclonal anti-Cterminal S6K1 antibodies [23] in dilution 1:100 in PBS overnight at $+4{ }^{\circ} \mathrm{C}$. The secondary FITC conjugated anti-rabbit antibody was applied in dilution 1:400 (Jackson ImmunoResearch) in $100 \mu 1$ PBS. The samples were embedded into Mowiol (Sigma) medium containing 2,5\% DABCO (Sigma) and $0,5 \mathrm{mg} / \mathrm{ml}$ DAPI (Pierce). All microscopy studies were performed using Zeiss LSM 510 META microscope (Germany). MTT assay. The $p 85^{-} / p 70^{-} / p 60^{-}$HEK-293 and wtHEK-293 cells were seeded in 96-well plates at a density of 5000 cells in $100 \mu 1$ per well and grown for 24, 48 and 72 hours. At the end of incubation, $20 \mu \mathrm{l}$ of $5 \mathrm{mg} / \mathrm{ml}$ MTT (3-(4,5-dimethylthiazol-2-yl)-2,5-diphenyltetrazolium bromide) were added to each well and incubated for $3 \mathrm{~h}$. Following incubation with MTT, $150 \mu \mathrm{l}$ of DMSO was added to dissolve formazan crystals and absorbance was measured at $570 \mathrm{~nm}$. Experiments were performed in triplicate.
Scratch assay. $p 85^{-} / p 70^{-} / p 60^{-}$HEK-293 and wtHEK-293 were plated onto a 35-mm dish and grown until $100 \%$ confluence to form a monolayer. A scratch was created with a pipette tip across the diameter of the dish. The cells were washed once with PBS and then replaced with fresh medium. At time points of 0 and $24 \mathrm{~h}$ of incubation, the cells were examined using Leica DM 1000 microscope, the images were acquired and further analysed quantitatively by ImageJ that measured the distance $(\mu \mathrm{m})$ travelled during the $24 \mathrm{~h}$ time frame. Each experiment was repeated three times.

Statistical analysis. All results are expressed as the mean \pm standard deviation (S.D.) from three independent experiments. Statistical significance between two groups was determined by using Student's $t$-test. The difference between groups was considered to be statistically significant at $p<0.01$ and $p<0.005$.

\section{Results and Discussion}

S6K1 gene gives rise to a number of S6K1 isoforms through usage of alternate ATG start sites (p85-S6K1 and p70-S6K1) or via translation of alternatively spliced mRNA (p31-S6K1 or S6K1-isoform 2) (reviewed in [1, 2]). According to existing data, translation of the S6K1 proteins may be initiated from two start codons all being present in the S6K1 transcript variant encoding the $\mathrm{p} 85$-protein causing expression of $\mathrm{p} 85$-S6K1 and $\mathrm{p} 70-\mathrm{S} 6 \mathrm{~K} 1$, respectively. The origin of another S6K1 isoform (p60-S6K1) missing a part of an N-terminal region is not known, however, one cannot exclude that it may represent a protein translated from the alternative translation start site [7] that represents a functionally active S6K1 isoform. We believe that $\mathrm{p} 60$ is translated from the third ATG located $87 \mathrm{bp}$ downstream 
of the second ATG that is a translation start for the p70-S6K1 isoform (Fig. 1).

In this work we aimed to generate HEK-293 cell lines with disrupted expression of S6K1 isoforms, including p85, p70 and p60, applying CRISPR/Cas9-mediated gene editing. Taking into account the prediction that p60-S6K1 isoform could be translated from the alternative translation start site, we designed gRNA (20 nt) targeting 279-298 bp region downstream of the third ATG (Fig. 1).

The reason for why the HEK-293 cells became a choice in this work is that they can be easily and promptly reproduced and maintained, as well as they allow high efficiency of transfection [24]. In addition, they are wellstudied in context of S6K1-dependent signaling. HEK-293 cell line is considered to be hypotriploid. Nevertheless, their modal chromosome number may differ depending upon the source of the HEK-293 cells [25, 26]. Thus any individual HEK-293 cell can bear a different number of RPS6KB1 gene copies, and in case CRISPR/Cas9 approach is applied, each copy can be mutated by the CRISPR/ Cas9 system in a distinct way within a cell.
To generate S6K1 knockout, we transfected the HEK-293 cells with pSpCas9(BB)-2A-Puro (PX459) V2.0 encoding anti-p85/p70/p60-S6K1 gRNA with following $48 \mathrm{~h}$ selection. Upon selection, six clones were picked up and checked for S6K1 lesions by Western blot technique using antibodies specific to the C-terminal (aa 453-525) region of S6K1 [23]. Wild type HEK-293 cells (wtHEK-293) were used as control cells.

S6K1 specific antibodies revealed targeting of all the S6K1 isoforms by anti-p85/p70/p60 gRNA. The S6K1 knockout in HEK-293 cells was confirmed in three out of six clones (\#4 6) by Western blot analysis (Fig. 2). In one clone (\#3), we observed a significant downregulation of all S6K1 isoforms. That may represent the case when at least one allele left intact. In addition, one of the generated clones (\#1) expressed a novel S6K1-related polypeptide that is longer than $\mathrm{p} 70$-S6K1, and other two clones $(\# 1, \# 2)$ expressed a polypeptide with electrophoretic mobility similar to that of p60-S6K1. Expression of the S6K1-related peptides may occur due to to a randomness of mutations caused by NHEJ action after a CRISPR/Cas9-mediated DNA cleavage.
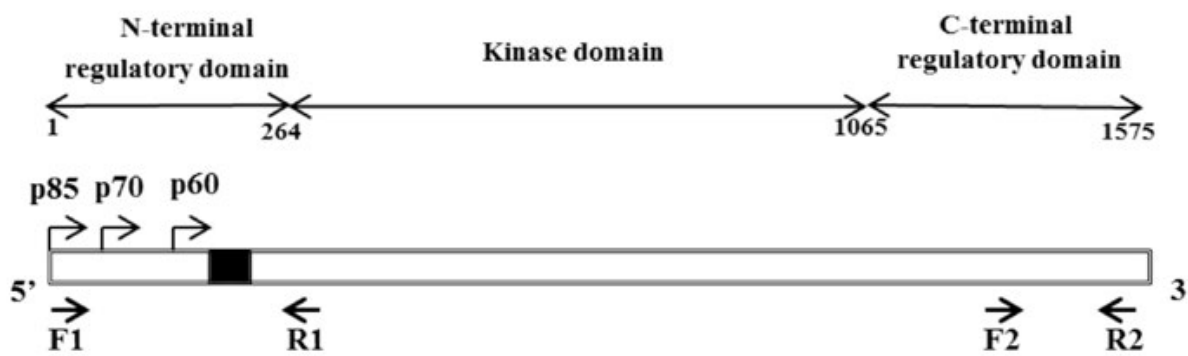

Fig. 1. The schematic representation of S6K1 domain organization and gRNA design for S6K1 gene editing using CRISPR/Cas9 genome editing technology. The figure shows the S6K1 transcript encoding the p85-, p70- and p60S6K1 isoforms with three corresponding alternative start sites (including the hypothetical third start for p60-S6K1) designated as bent right arrows. A black colored region depicts the gRNA targeted region (279-298 nucleotides). F1 and R1 are primers used for PCR analysis of the targeted 5'-region in the S6K1 transcript; F2 and R2 are primers used for PCR analysis of the intact 3'-region of the S6K1 transcript. 
Taking into account that our goal was to generate HEK-293 cells that would not express any of known S6K1 isoforms, we selected the

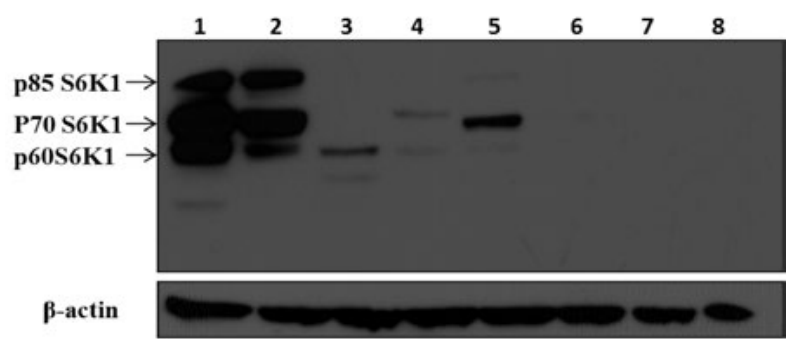

Fig. 2. Analysis of S6K1 isoforms expression in clones of HEK293 cells after S6K1 gene editing. Western-blot analysis of HEK293 cell lysates with antibodies specific to the C-terminal region of S6K1. $\beta$-actin was used as a loading control. 1 - MCF-7wt; 2 - HEK293wt; 3-8 HEK293 clones ( 1 - 6) with gRNA targeted S6K1 gene. clones (\#5 and \#6) where expression of S6K1 was not detected at all by anti-S6K1 antibodies specific to the kinase C-terminus for further analysis.

The following immnofluorescent analysis of selected clones with the same anti-S6K1 antibodies specific to the kinase C-terminal region have confirmed a complete loss of S6K1 expression (Fig. 3). In addition, alterations in selected clones \#5 and \#6 were confirmed by RT-PCR analysis using oligonucleotides specific to the downstream and upstream region of the targeted sequence (Fig. 4). PCR analysis of S6K1 mRNA expression using oligonucleotides specific to the untargeted 3'-sequence did not reveal any alterations suggesting that

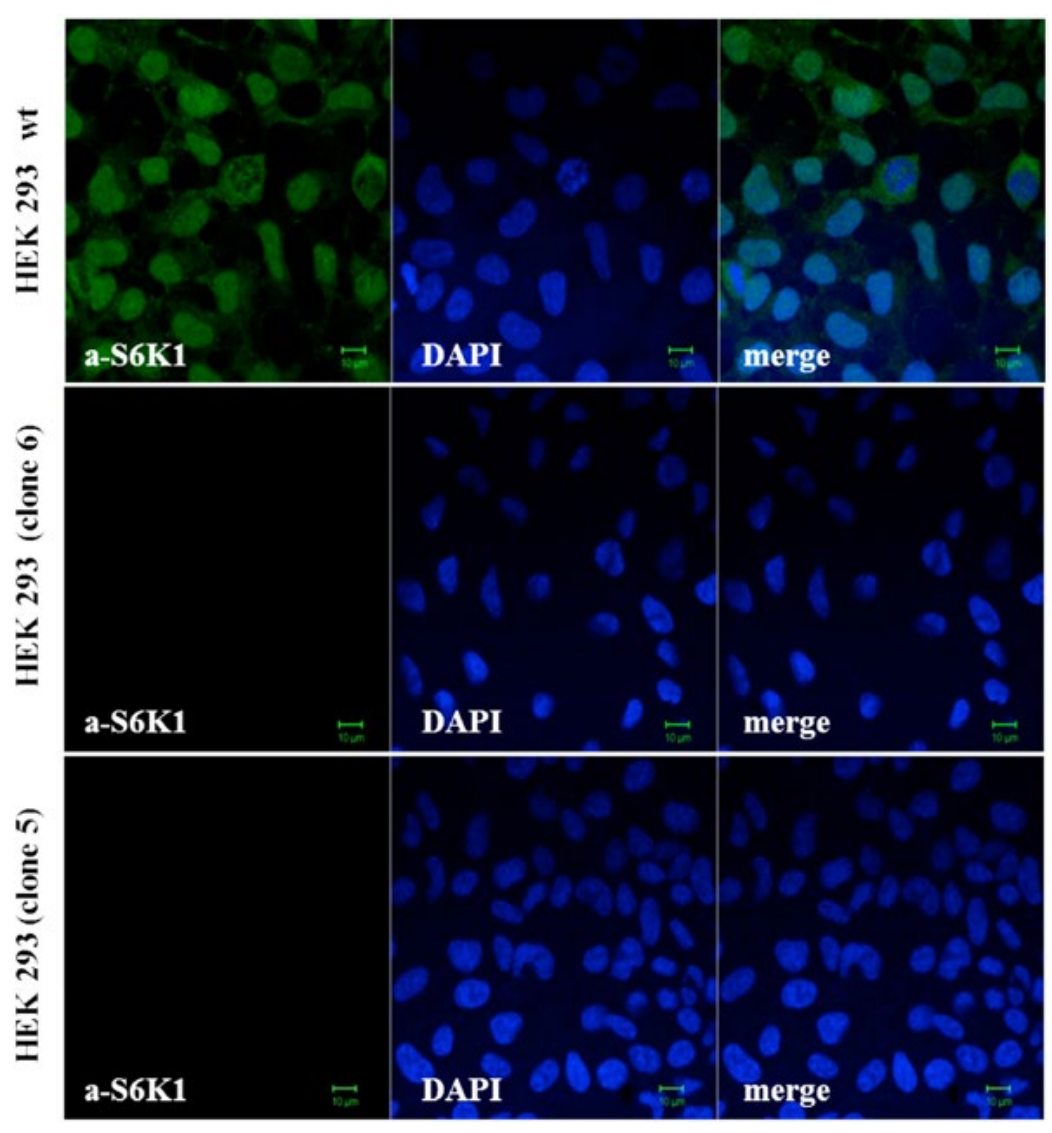

Fig. 3. Immunofluorescent detection of S6K1 with antibodies specific to the C-terminal region of S6K1 in parental HEK-293 cells and in HEK293 clones (5 and 6) after CRISPR/Cas9 induced S6K1 gene editing. 


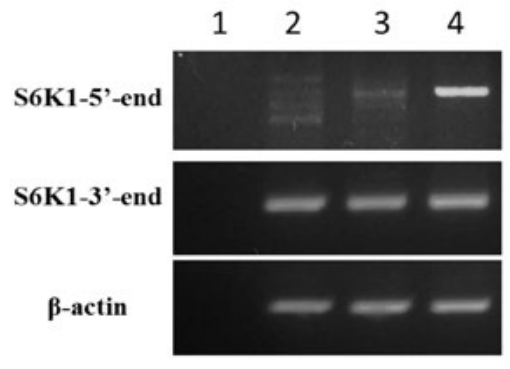

Fig. 4. PCR analysis of cDNA isolated from generated HEK-293 clones after CRISPR/Cas9 induced editing of the S6K1 gene. A top panel represents PCR analysis of cDNA selected clones with primers specific to 5'-end of S6K1 transcripts (F1, R1) where targeted sequence is located. The resulted PCR product contains a mutated sequence. The other panels show PCR products with primers specific to 3 '-end of S6K1 (F2, R2) and $\beta$-actin. 1 - negative control; 2 - clone 5; 3 - clone 6; 4 - wtHEK-293.
CRISPR/Cas9 genome editing did not affected S6K1 expression on a transcriptional level.

We also observed Cas9 nuclease expression in all the individual CRISPR/Cas9 clones (data not shown). Therefore, the S6K1 knockout cells (clone \#5, \#6) could be used in studies involving only transient (but not stable) S6K1 isoforms expression.

After we generated the S6K1 knockout HEK293 cells, our next goal was to estimate an impact of S6K1 gene disruption on phosphorylation of the major S6K1 substrates and some cellular processes controlled by intact $\mathrm{S} 6 \mathrm{~K} 1$, including cell proliferation and migration. We first examined the phosphorylation pattern of the S6K1regulated proteins. We did not observe any differences in the phosphorylation status of ribosomal protein S6 (rpS6) on both Ser235/236 and Ser240/244 between wtHEK-293 and $p 85^{-} / p 70^{-/}$ p60- HEK-293 (Fig. 5). Indeed, apart from S6K1 there are several other AGC kinases that target rpS6, including RSK (phosphorylates rpS6 on Ser235/236) and S6K2 (promotes phosphorylation of rpS6 on Ser235/236/240/244). Studies using both cultured mammalian cells with RNAimediated S6K1 knockdown and S6K1 knockout mice report a decrease in rpS6 phosphorylation on each of four sites mentioned above [27, 28]. In our cells treated with CRISPR/Cas9, however, RSK and S6K2 appear to completely compensate for S6K1-mediated rpS6 phosphorylation. Such a discrepancy could be explained by using different cell types and/or various methods of S6K1 silencing. Except for rpS6, several other proteins implicated in translation regulation also represent well-known S6K1 substrates, including eIF4B and eEF-2K. Additionally, these S6K1-regulated substrates are also controlled by RSK-mediated phosphorylation. Our data shows that S6K1 knockout HEK-293 display a lower level of eI-

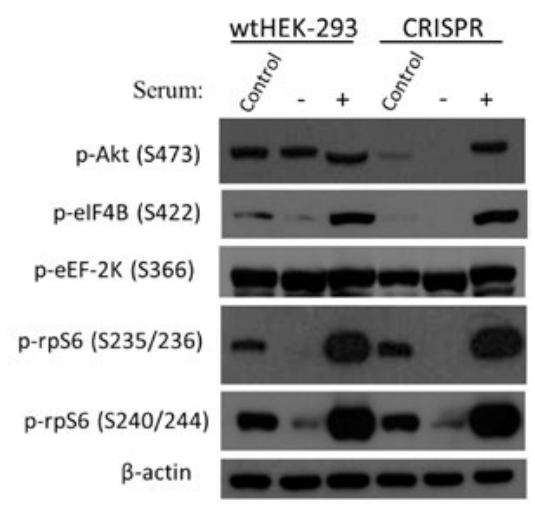

Fig. 5. Effect of $\mathrm{S} 6 \mathrm{~K} 1$ gene disruption on $\mathrm{Akt} / \mathrm{mTOR} / \mathrm{S} 6 \mathrm{~K} 1$ signaling in HEK293 cells. After 24 hours of serum starvation, HEK-293 cells with S6K1 gene knockout were treated with $20 \%$ fetal bovine serum (FBS) for 1 hour. Protein lysates were prepared from the cells and analyzed for the Akt $/ \mathrm{mTOR} /$ S6K1 signalling pathway by Western blotting. Antibody against $\beta$-actin was used to ensure each protein sample was loaded equally. 


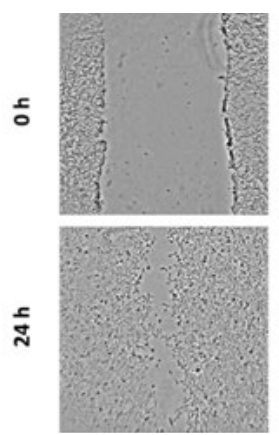

(1)

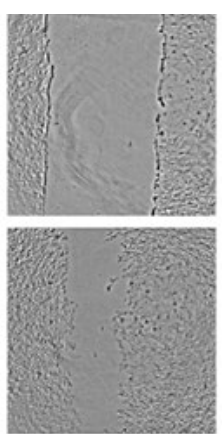

(2)

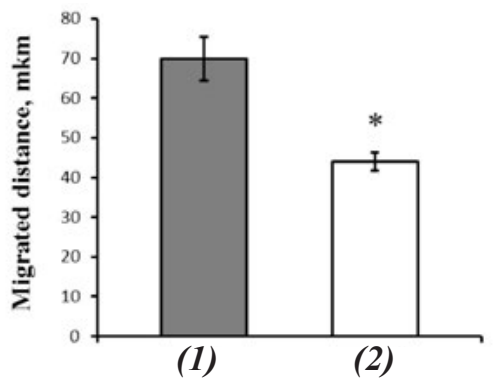

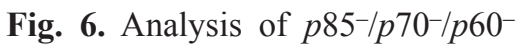
HEK-293 migration by in vitro scratch assay. The confluent $p 85^{-/}$ $p 70^{-} / p 60^{-}$HEK-293 (2) cells were subjected to in vitro scratch assay with images captured at 0 and $24 \mathrm{~h}$ after incubation. *, p $<0.01$, versus wtHEK-293 (1). Experiments were repeated in triplicate.
F4B phosphorylation on Ser422 compared to HEK-293, but the levels of phospho-eEF-2K (Ser366) remain unchanged (Fig. 5). Consistently, a similar pattern of eIF4B phosphorylation was observed after S6K1 knockdown [27].

Surprisingly, Akt Ser473 phosphorylation significantly decreased in response to S6K1 knockout in comparison with wtHEK-293 (Fig. 5). In contrast to our results, evidence exists for an increase of Akt Ser473 phosphorylation in S6K1 knockdown rhabdomyosarcoma cell lines [29]. Meanwhile, recent data obtained suggest either unchanged phosphoAkt Ser473 levels or even a drop in Ser473 phosphorylation when authors applied methods of chemical or genetic inhibition of S6K1, respectively in [30]. Additionally, MEFs derived from $S 6 \mathrm{~K}^{-/-} S 6 \mathrm{~K} 2^{-/-}$mice displayed normal levels of Akt Ser473 phosphorylation [31].

A number of studies demonstrated the ability of S6K1 to regulate actin cytoskeleton and a cell migration rate $[32,33]$. In comparing wtHEK-293 with $p 85^{-} / p 70^{-} / p 60^{-}$HEK-293, we observed a decrease in migration rate of the $p 85^{-} / p 70^{-} / p 60^{-}$ HEK-293 cells (Fig. 6), further supporting the idea that $\mathrm{S} 6 \mathrm{~K} 1$ at least in part controls cell motility.

Since S6K1 promotes anabolic processes, including protein and lipid synthesis [1], within the mTORC1 signaling network in a cell, an ability of a cell to grow and proliferate is also dependent on S6K1. In our study, we applied MTT assay to estimate a rate of $p 85^{-} / p 70^{-} / p 60^{-}$ HEK-293 cell proliferation. Apparently, the $p 85^{-} / p 70^{-} / p 60^{-}$HEK-293 cells grew at a lower rate than control wtHEK-293 (Fig. 7). Our results underscore the role for S6K1 in regulation of cell growth and proliferation in agreement with the data reported by other authors [34].

We assume that reduced cell proliferation and migration rates of $p 85^{-} / p 70^{-} / p 60^{-}$HEK-

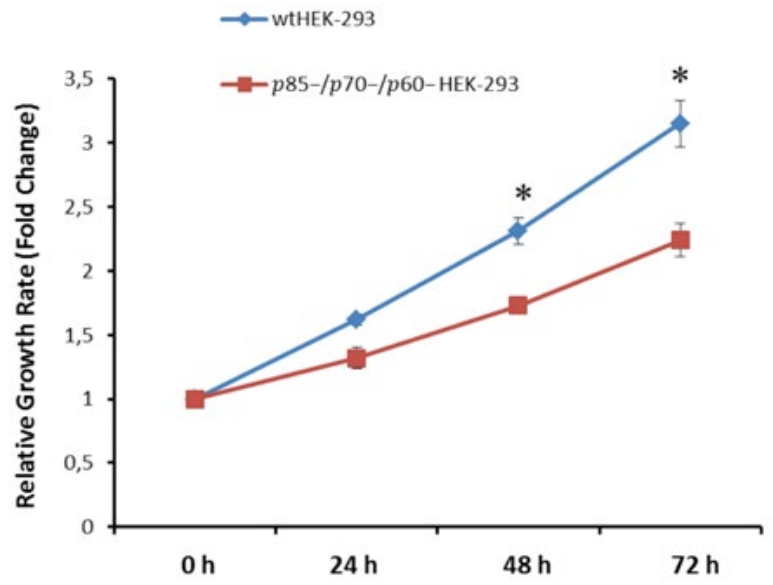

Fig. 7. CRISPR/Cas9-mediated knockout of S6K1 inhibits HEK-293 cell proliferation. $p 85^{-} / p 70^{-} / p 60^{-}$HEK-293 and wtHEK-293 were seeded in 96-well plates and cultured for 24, 48 and 72 hours. At the end of the incubation, MTT was added and absorbance measured. The data are presented as the mean \pm S.D. ${ }^{*} p<0.005$. 
293 could be caused by decreased Akt Ser473 phosphorylation. Akt is one of the cell cycle regulators; it can also be critical for migratory properties of a cell (reviewed in [35]). Even though S6K1 represents a well-known negative regulator of Akt via a negative feedback loop downregulating gene expression of IRS1/2 [36, 37], several other less-studied mTOR-dependent feedbacks can negatively modulate Akt function $[38,39]$. Possibly, some of these feedback loops become hyper-activated under the condition of CRISPR-mediated S6K1 knockout in the HEK-293 cells. Further studies are required to define the mechanism underlying Akt regulation by S6K1 in the HEK-293 cells. In conclusion, we generated mutant HEK-293 cells with a complete loss of p85/p70/p60-S6K1 protein expression by CRISPR/Cas9 gene editing. The generated cells can be used for creation of cell models with ectopic expression of different S6K1 isoforms enabling to gain more detailed insight into S6K1 isoforms cellular function. These cells also provide an opportunity to investigate crosstalk or compensatory mechanisms existing between different cell signaling pathways which regulate fundamental cellular processes.

\section{Acknowledgements}

This work was supported in part by a fellowship from Boehringer Ingelheim Fonds (BIF) awarded to Igor Zaiets.

\section{REFERENCES}

1. Magnuson B, Ekim B, Fingar DC. Regulation and function of ribosomal protein S6 kinase (S6K) within mTOR signalling networks. Biochem J. 2012;441(1):1-21.

2. Fenton TR, Gout IT. Functions and regulation of the $70 \mathrm{kDa}$ ribosomal S6 kinases. Int J Biochem Cell Biol. 2011;43(1):47-59.
3. Zoncu R, Efeyan A, Sabatini DM. mTOR: from growth signal integration to cancer, diabetes and ageing. Nat Rev Mol Cell Biol. 2011;12(1):21-35.

4. Dann SG, Selvaraj A, Thomas G. mTOR Complex1S6K1 signaling: at the crossroads of obesity, diabetes and cancer. Trends Mol Med. 2007;13(6):252-9.

5. Hoeffer CA, Klann E. mTOR signaling: at the crossroads of plasticity, memory and disease. Trends Neurosci. 2010;33(2):67-75.

6. Grove JR, Banerjee P, Balasubramanyam A, Coffer PJ, Price DJ, Avruch J, Woodgett JR. Cloning and expression of two human p70 S6 kinase polypeptides differing only at their amino termini. Mol Cell Biol. 1991;11(11):5541-50.

7. Kim D, Akcakanat A, Singh G, Sharma C, Meric-Bernstam $F$. Regulation and localization of ribosomal protein S6 kinase 1 isoforms. Growth Factors. 2009;27(1):12-21.

8. Pende M, Kozma SC, Jaquet M, Oorschot V, Burcelin R, Le Marchand-Brustel Y, Klumperman J, Thorens B, Thomas G. Hypoinsulinaemia, glucose intolerance and diminished beta-cell size in S6K1deficient mice. Nature. 2000; 408(6815):994-7.

9. Carnevalli LS, Masuda K, Frigerio F, Le Bacquer O, Um SH, Gandin V, Topisirovic I, Sonenberg N, Thomas $G$, Kozma SC. S6K1 plays a critical role in early adipocyte differentiation. Dev Cell. 2010; 18(5):763-74.

10. Um SH, Frigerio F, Watanabe M, Picard F, Joaquin M, Sticker M, Fumagalli S, Allegrini PR, Kozma SC, Auwerx J, Thomas G. Absence of S6K1 protects against age-and diet-induced obesity while enhancing insulin sensitivity. Nature. 2004;431(7005):200-5.

11. Bärlund M, Monni O, Kononen J, Cornelison R, Torhorst J, Sauter G, Kallioniemi OLLI-P, Kallioniemi A. Multiple genes at 17q23 undergo amplification and overexpression in breast cancer. Cancer Res. 2000;60(19):5340-4.

12. Ismail HMS. Overexpression of S6 kinase 1 in brain tumours is associated with induction of hypoxiaresponsive genes and predicts patients' survival. J Oncol. 2012; 2012:416927.

13. Castellvi J, Garcia A, Rojo F, Ruiz-Marcellan C, Gil A, Baselga J, Ramon y Cajal S. Phosphorylated $4 \mathrm{E}$ binding protein 1: a hallmark of cell signaling that correlates with survival in ovarian cancer. Cancer. 2006;107(8):1801-11. 
14. Filonenko VV, Tytarenko R, Azatjan SK, Savinska LO, Gaydar YA, Gout IT, Usenko VS, Lyzogubov $V V$. Immunohistochemical analysis of S6K1 and S6K2 localization in human breast tumors. Exp Oncol. 2004;26(4):294-9.

15. Lyzogubov V, Khozhaenko Y, Usenko V, Antonjuk S, Ovcharenko G, Tikhonkova I, Filonenko V. Immunohistochemical analysis of Ki-67, PCNA and S6K1/2 expression in human breast cancer. Exp Oncol. 2005;27(2):141-4.

16. Bärlund M, Forozan F, Kononen J, Bubendorf L, Chen Y, Bittner ML, Torhorst J, Haas P, Bucher C, Sauter G, Kallioniemi OP, Kallioniemi A. Detecting activation of ribosomal protein S6 kinase by complementary DNA and tissue microarray analysis. J Natl Cancer Inst. 2000;92(15):1252-9.

17. van der Hage JA, van den Broek LJ, Legrand C, Clahsen PC, Bosch CJ, Robanus-Maandag EC, van de Velde CJ, van de Vijver MJ. Overexpression of P70 S6 kinase protein is associated with increased risk of locoregional recurrence in node-negative premenopausal early breast cancer patients. $\mathrm{Br} J$ Cancer. 2004;90(8):1543-50.

18. Bostner J, Karlsson E, Pandiyan MJ, Westman H, Skoog L, Fornander T, Nordenskjöld B, Stål O. Activation of Akt, mTOR, and the estrogen receptor as a signature to predict tamoxifen treatment benefit. Breast Cancer Res Treat. 2013;137(2):397-406.

19. Bostner J, Karlsson E, Eding CB, Perez-Tenorio G, Franzén H, Konstantinell A, Fornander T, Nordenskjöld B, Stål O. S6 kinase signaling: tamoxifen response and prognostic indication in two breast cancer cohorts. Endocr Relat Cancer. 2015;22(3):331-43.

20. Terns RM, Terns MP. CRISPR-based technologies: prokaryotic defense weapons repurposed. Trends Genet. 2014;30(3):111-8.

21. Sorek R, Lawrence CM, Wiedenheft B. CRISPRmediated adaptive immune systems in bacteria and archaea. Annu Rev Biochem. 2013;82:237-66.

22. Bhaya D, Davison M, Barrangou R. CRISPR-Cas systems in bacteria and archaea: versatile small RNAs for adaptive defense and regulation. Annu Rev Genet. 2011;45:273-97.

23. Savinska LO, Kijamova RG, Pogrebnoy PV, Ovcharenko GV, Gout IT, Filonenko VV. Comparative characterization of S6 kinase $\alpha$ and $\beta$ isoforms expression in mammalian tissues. Biopolym Cell. 2001; 17(5):374-9.

24. Thomas P, Smart TG. HEK293 cell line: a vehicle for the expression of recombinant proteins. $J$ Pharmacol Toxicol Methods. 2005;51(3):187-200.

25. Lin YC, Boone M, Meuris L, Lemmens I, Van Roy N, Soete A, Reumers J, Moisse M, Plaisance S, Drmanac R, Chen J, Speleman F, Lambrechts D, Van de Peer Y, Tavernier J, Callewaert N. Genome dynamics of the human embryonic kidney 293 lineage in response to cell biology manipulations. Nat Commun. 2014;5:4767.

26. Bylund L, Kytölä S, Lui WO, Larsson C, Weber G. Analysis of the cytogenetic stability of the human embryonal kidney cell line 293 by cytogenetic and STR profiling approaches. Cytogenet Genome Res. 2004;106(1):28-32.

27. Chauvin C, Koka V, Nouschi A, Mieulet V, HoareauAveilla C, Dreazen A, Cagnard N, Carpentier W, Kiss T, Meyuhas O, Pende M. Ribosomal protein S6 kinase activity controls the ribosome biogenesis transcriptional program. Oncogene. 2014;33(4):474-83.

28. Dibble CC, Asara JM, Manning BD. Characterization of Rictor phosphorylation sites reveals direct regulation of mTOR complex 2 by S6K1. Mol Cell Biol. 2009;29(21):5657-70.

29. Wan X, Harkavy B, Shen N, Grohar P, Helman LJ. Rapamycin induces feedback activation of Akt signaling through an IGF-1R-dependent mechanism. Oncogene. 2007;26(13):1932-40.

30. Wang X, Yue P, Tao H, Sun SY. Inhibition of p70S6K does not mimic the enhancement of Akt phosphorylation by rapamycin. Heliyon. 2017;3(8):e00378.

31. Hsu PP, Kang SA, Rameseder J, Zhang Y, Ottina KA, Lim D, Peterson TR, Choi Y, Gray NS, Yaffe MB, Marto JA, Sabatini DM. The mTOR-regulated phosphoproteome reveals a mechanism of mTORC1mediated inhibition of growth factor signaling. Science. 2011;332(6035):1317-22.

32. Berven LA, Willard FS, Crouch MF. Role of the p70(S6K) pathway in regulating the actin cytoskeleton and cell migration. Exp Cell Res. 2004;296(2):183-95.

33. Liu L, Li F, Cardelli JA, Martin KA, Blenis J, Huang $S$. Rapamycin inhibits cell motility by sup- 
pression of mTOR-mediated S6K1 and 4E-BP1 pathways. Oncogene. 2006;25(53):7029-40.

34. Fingar DC, Richardson CJ, Tee AR, Cheatham L, Tsou C, Blenis J. mTOR controls cell cycle progression through its cell growth effectors S6K1 and 4E-BP1/eukaryotic translation initiation factor 4E. Mol Cell Biol. 2004;24(1):200-16.

35. Manning BD, Cantley LC. AKT/PKB signaling: navigating downstream. Cell. 2007;129(7):1261-74.

36. Um SH, Frigerio F, Watanabe M, Picard F, Joaquin M, Sticker M, Fumagalli S, Allegrini PR, Kozma SC, Auwerx J, Thomas G. Absence of S6K1 protects against age- and diet-induced obesity while enhancing insulin sensitivity. Nature. 2004;431(7005):200-5.

37. Tremblay F, Brûlé S, Hee Um S, Li Y, Masuda K, Roden M, Sun XJ, Krebs M, Polakiewicz RD, Thomas $G$, Marette A. Identification of IRS-1 Ser-1101 as a target of S6K1 in nutrient- and obesity-induced insulin resistance. Proc Natl Acad Sci U S A. 2007;104(35):14056-61.

38. Ozes ON, Akca H, Mayo LD, Gustin JA, Maehama T, Dixon JE, Donner DB. A phosphatidylinositol 3-kinase/Akt/mTOR pathway mediates and PTEN antagonizes tumor necrosis factor inhibition of insulin signaling through insulin receptor substrate-1. Proc Natl Acad Sci U S A. 2001;98(8):4640-5.

39. Hsu PP, Kang SA, Rameseder J, Zhang Y, Ottina KA, Lim D, Peterson TR, Choi Y, Gray NS, Yaffe MB, Marto JA, Sabatini DM. The mTOR-regulated phosphoproteome reveals a mechanism of mTORC1mediated inhibition of growth factor signaling. Science. 2011;332(6035):1317-22.

\section{Створення стабільних ліній клітин НЕК-293 3 порушеною експресісю ізоформ кінази рибосомного білка S6 (S6K1) за допомогою системи редагування генома CRISPR/Cas9}

I. В. Заєць, А. С. Сівченко, А. І. Хоруженко, В. В. Філоненко

Мета. Створити клітини НЕК293 з порушеною експресією S6K1 ізоформ: p85, p70 і Р60. Методи. CRISPR/cas9 система редагування генома, Вестернблот, імунофлуоресцентний аналіз, ПЛР-аналіз, МТТ тест, метод «раневої поверхні». Результати. Отримано декілька клонів клітин НЕК-293 з повною втратою експресії білка p85/p70/p60-S6K1. Було оцінено ефект нокауту p85/p70/p60-S6K1 на Akt/mTORC1/S6K1 сигналінг та клітинні проліферацію і міграцію. Висновки. Створені клітинні лінії можуть бути використані для вивчення ролі, яку відіграє S6K1 в фізіології клітини, що дозволяє отримати більш детальне уявлення про клітинні функції ізоформ S6K1. Клітини $p 85^{-} / p 70^{-} /$ p60- НЕК-293 виявляють знижений рівень фосфорилювання Akt по Cep473 і подальше пригнічення швидкості клітинного росту разом з інгібуванням клітинної рухливості.

Кл юч ов і сл о в а: mTOR/S6K1 сигналювання, CRISPR/Cas9, ізоформи S6K1.

\section{Создание стабильных линий клеток НЕК-293 \\ с нарушенной экспрессией изоформ киназы рибосомного белка S6 (S6K1) при помощи системы редактирования генома CRISPR/Cas9}

И. В. Заец, А. С. Сивченко, А. И. Хоруженко, В. В. Филоненко

Цель. Создать клетки НЕК293 с нарушенной экспрессией S6K1 изоформ: p85, p70 и P60. Методы. CRISPR/ cas9 система редактирования генома, Вестерн-блот, иммунофлуоресцентный анализ, ПЦР-анализ, МТТ тест, метод «раневой поверхности». Результаты. Получено несколько клонов клеток НЕК-293 с полной потерей экспрессии белка p85/p70/p60-S6K1. Была проведена оценка влияния нокаута p85/p70/p60-S6K1 на Akt/mTORC1/S6K1 сигналинг и клеточные пролиферацию и миграцию. Выводы. Созданные клеточные линии могут быть использованы для изучения роли, которую играет S6K1 в физиологии клетки и позволить получить более детальное представление о клеточных функциях изоформ S6K1. Клетки $p 85^{-} / p 70^{-} / p 60^{-}$HEK293 показывают пониженный уровень фосфорилирования Akt по Cep473 и дальнейшее угнетение скорости клеточного роста вместе с ингибированием клеточной подвижности.

Ключевы е слова: mTOR/S6K1 сигналинг, CRISPR/Cas9, изоформы S6K1.

Received 27.05.2017 